\title{
LIFEWORLD, CIVILISATION, SYSTEM: PATOČKA AND HABERMAS ON EUROPE AND ITS CRISIS
}

\section{FRANCESCO TAVA}

Postdoctoral Scholar KU Leuven, Institute of Philosophy, Husserl-Archives: Center for Phenomenology and Continental Philosophy, 3000 Leuven, Belgium.

E-mail: francesco.tava@kuleuven.be

The aim of this article is to show how both Jan Patočka and Jürgen Habermas, starting from a reinterpretation of the idea of «lifeworld», engaged a critique of modern civilisation, aiming (with different outcomes) at a redefinition of the concept of political community. In order to achieve this goal, I firstly focus on Patočka's understanding of modern rational civilisation and its attempt to fix the fracture between «life» and «world». At this stage, I take also advantage of Hans Blumenberg's distinction between these two terms, in order to better clarify Patočka's stance on this problem. Secondly, I analyse Habermas' ideas of lifeworld and system, and their uncoupling in modern societies, as well as the reemergence of this issue in Habermas' recent works on the European economic and political crisis. Finally, I focus on the very different ways in which Patočka and Habermas tackled the ideas of conflict and crisis in contemporary world, also in view of a possible path out of this crisis through a re-constitution of Europe.

Key words: Lifeworld, civilisation, communicative action, system, crisis, Europe, solidarity, community.

\section{ЖИЗНЕННЫЙ МИР, ЦИВИЛИЗАЦИЯ, СИСТЕМА: ПАТОЧКА И ХАБЕРМАС О ЕВРОПЕ И ЕЁ КРИЗИСЕ}

\section{ФРАНЧЕСКО ТАВА}

Пост-докторант Университета Лёвена, Институт философии, Архив Гуссерля: Центр феноменологии и континентальной философии, 3000 Лёвен, Бельгия.

E-mail: francesco.tava@kuleuven.be

Цель этой статьи - показать как в равной мере Ян Паточка и Юрген Хабермас, начав с обновления идеи «жизненного мира», обратились к критике современной цивилизации, со сходной целью - заново определить понятие политической общности (при всей различности результатов, к

(C) FRANCESCO TAVA, 2016 
которым они пришли). Для того чтобы достичь этой цели, я для начала фокусирую внимание на современной рациональной цивилизации, как её понимал Паточка, и на его попытке залатать трещину между «жизнью» и «миром». На этом этапе я как раз буду опираться на то, как различает эти два понятия Ханс Блюменберг; это поможет лучше прояснись позицию Паточки в данном контексте. Затем я проанализирую представления Хабермаса о жизненном мире и системе, и проблему их раскола в современных обществах, равно как и возрождение интереса к этой теме в недавних работах Хабермаса о Европейском экономическом и политическом кризисе. В заключение я сосредоточусь на разборе тех разных способов, которыми Паточка и Хабермас решали проблемы конфликта и кризиса в современном мире, с оглядкой на поиск возможного выхода из этого кризиса путем пересборки Европы.

Ключевые слова: Жизненный мир, цивилизация, система, кризис, Европа, сообщество.

\section{LIFEWORLD}

In an essay he wrote in the early 1970s, commenting on Husserl's Crisis of the European Sciences, Patočka gives a definition of the «lifeworld» which deviates both from Husserl's definition and from his previous insights into this same topic. ${ }^{1}$ In particular he argues that:

Our life-world is, after all, primordially a world of human practice, a world where people eat and work and devote themselves to tasks which they carry out by relying on that ever available yet ever overlooked resource of our physical, corporeal existence. Does not this world open itself more to my «I can» than to my «I perceive» or my «I observe»? (Patočka, 1989a, 234) $)^{2}$

Focusing his attention on the practical aspects of the lifeworld, Patočka goes as far as to say that the aforementioned «I can» which already at the level of Lebenswelt characterises human existence, is not a generic action, but rather an action already oriented - although still in an unthematic fashion - toward what in this world we might consider as good or evil:

This life-world is a world of good and evil, and its subjectivity is that of the drama of

\footnotetext{
1 Patočka had already addressed the topic of the «lifeworld» or «natural world» in his habilitation thesis in 1936: (Patočka, 2008). About the genesis and the evolution of this concept in Patočka's philosophy, especially in relation with the works of Husserl and Heidegger, see: (Srubar, 2002). For a analysis of Husserl's concept of the lifeworld, with regard to the views of other authors, including Patočka, see: (Vetter, 2003).

2 About Patočka's late critique of Husserl's concept of lifeworld, see also: (Patočka,1989b; 1994).
} 
good and evil, the good and evil of an essentially finite being who cannot live except by projecting nonthematically, ever «knowing» that this projection is accompanied by the shadow of extreme possibility of not projecting at all. (Patočka, 1989a, 235-236)

The lifeworld according to Patočka is therefore not a «given» world, i.e. a world which can be easily taken for granted, as though its given or current orientation were the «real» one, notwithstanding the human deeds aimed at the modification or the enhancement of this world. Stating that the lifeworld is first and foremost the space of the human «I can» as it is originally oriented toward some notion of good or evil, Patočka bestows a precise ethical responsibility upon men and women, which consists in the possibility of actively changing their lifeworld through their actions; not simply surrendering to the «natural» (i.e. unalterable) character of this world, but courageously facing its crises and contradictions, and also striving to find a path out of them. Moreover, this conception also gives the lifeworld a process character: it is always a being-toward and the subject is likewise also always being towards some notion of the good.

\section{CIVILISATION AND EUROPE}

Once the lifeworld has been recognised as the primary focus of ethical reflection, i.e. as the real world in which we orient ourselves through our free actions toward particular but only vaguely sketched notions of the good, it finally becomes possible to recognise the crisis that is affecting this world, and also respond to it. Hans Blumenberg cogently emphasised how modernity can be interpreted as a fracture of this concept of lifeworld, due to a substantial detachment of the two elements which compose this concept - «life» and «world» (Blumenberg, 1986, 7 ff.). While on the one hand «world» gets bigger and bigger, thanks to scientific and technical development, until it ends up being conceived no more as «earth» but rather as infinite «universe» on the other hand «life» is subjected to a gradual reduction, until it is confined to the private realm of the individual, that is the realm of feelings and passions, where no precise and rational knowledge is admitted. Focusing all its cognitive efforts on the «world» rather than on «life» humanity was

able to achieve the remarkable scientific advancements that characterised modernity, culminating in the twentieth-century's great discoveries. However, a comparable progress did not occur in human life and in the social and political institutions that regulate 
it, whose functioning seems to follow more intangible laws, compared to those which govern scientific reality.

By introducing the idea of «supercivilisation», in the mid-1950s (Patočka, 1996b), ${ }^{3}$ Patočka sought to define and explain humanity's greatest attempt to fix the fracture of the life-world, the attempt at leading life back to its original dwelling, that is, that world with which it seems to have lost contact. ${ }^{4}$ Although in sketching the supercivilisation concept Patočka never directly engages the idea of lifeworld, I think this definition can be maintained. The technique of power which characterises supercivilisation is not, in fact, simply directed toward circumscribed human institutions (like polities, laws, and social conventions), but rather to human life as such, in all its aspects and functions. ${ }^{5}$ In this sense, we can talk of supercivilisation as a project which is aimed at reconfiguring and enhancing human life in such a way that it can eventually regain its centrality within the world from which the advancements of technical science seem to have left it out. ${ }^{6}$ Achieving this goal would mean re-establishing a regnum hominis (human rule) over the world, despite all the attempts of modern science to put all that is «human» at the outskirts of the universe, excluding it from its fundamental mechanisms. To do this, a new political project emerged, starting from early modernity, which aimed at a complete rationalisation of every aspect of human life, in order to adapt it to the scientific standards of today. The idea of homo oeconomicus, widespread in classical political economics ${ }^{7}-$ i.e. the conception for which the human condition has to be

\footnotetext{
3 For an extensive analysis of this concept, see: (Homolka, 2015). About the importance of Patočka's idea of supercivilisation with regards to the civilisational theory, see: (Ârnason, 2003, 132 ff.).

4 Although for Patočka the first examples of supercivilisation can be tracked down already in early modern history (Patočka, 1996b, 247), as I will show in what follows it is only during the twentieth century that this process of rationalisation fully climaxed.

${ }^{5}$ «It is a well-known fact that this process, which originated in the area of mechanical sciences, as result of some discoveries in XIV century, spread to the whole modern lifestyle, and found its most potent manifestation in the capitalist enterprise, with its labour disciplination and world reification and banalisation. The result of this process were the phenomena of the division of labour and of the world market, the consequence of which was the rise of that huge web of objective relations, whose tentacles envelope this kind of life, ending up infringing on the whole world.» (Patočka, 1996b, 248). (All translations from Czech and German are made by the author)

${ }^{6}$ I am thankful to the anonymous reviewer who demanded this clarification.

7 This concept was firstly introduced by John Stuart Mill, in order to explain the necessary theoretical abstraction performed by political economy: «[Political economy] does not treat the whole of man's nature as modified by the social state, nor of the whole conduct of man in society. It is concerned with him solely as a being who desires to possess wealth, and who is capable to possess wealth, and who is capable of judging the comparative efficacy of means for obtaining that end.» (Mill, 2004, 250).
} 
considered as an objective and scientifically analysable entity, and the individual as nothing but a rational and self-interested actor, so that it becomes possible to deduce human nature and behaviour from general principles and with scientific accuracy might be seen as an attempt in this direction. While this conception may be valid as a simple theoretical abstraction, ${ }^{8}$ it proved to be de facto untenable, as soon as it starts to be considered as an exhaustive definition of the human being as such. In this circumstance, the mistake cannot be ascribed to science, whose method necessarily works through (explicitly recognised) abstractions and simplifications, but rather to whoever considers this abstraction a valid description of human being as such, overlooking their historically contingent peculiarities.

As Patočka clarifies in his essay on supercivilisation, twentieth-century history shattered this political project based on a widespread rationalisation of human existence, as it vividly showed the existence of irrational forces in human nature which still impinge upon the present, in spite of any attempt to discipline them. In describing the supercivilisation and the crisis into which it fell, Patočka wanted to unearth these irrational forces, whose re-emergence reveals the lifeworld's complexity. This complexity, which is already visible in light of the juxtaposition of the two elements which constitute this term, does not correspond to a fracture that could be fixed by merging these elements into a simple unity, as the rational supercivilising process aimed to do. On the contrary, human life is not and will never be a natural element of this world, but is rather something which always settles in it in a problematic way, not adapting itself to its natural structure, but rather shattering its fundaments. What Patočka suggests with his critique of the idea of supercivilisation, is the necessity to conceive life in light of all its conflicts and tragedies, appraising and not trying to overlook these problematic aspects. Questioning the «world of good and evil» means for Patočka precisely shedding light on the existential crisis and on the historical and political conflicts which characterised modern civilisation, from its genesis, until twentieth century's most tragic events.

\footnotetext{
8 In this respect, Antonio Gramsci cogently pointed out that rejecting the concept of homo oeconomicus because of its abstractness would be as much meaningless as rejecting, for instance, the use of the symbol « $\mathrm{H} 2 \mathrm{O}$ » for water. See: (Gramsci, 1975, 1948).
} 
The idea of a process of rationalisation, which essentially pertains to the concept of supercivilisation, refers back to Weber's conception of rationalisation, ${ }^{9}$ which was later recovered by critical theory, and especially by Adorno, Horkheimer, and Habermas. ${ }^{10}$ In central and eastern Europe this topic acquired an important echo especially during the 1960s, in a period of intense political ferment and efforts of reformation in the socialist countries, which Patočka experienced at first hand. ${ }^{11}$ What Patočka actually adds to this debate is firstly the characterisation of two different and opposing variants into which the supercivilisation branches out. Secondly, he underlines how these variants, since they are both grounded on the same principle of a rational accumulation of power, also run, for different reasons, into the same internal dialectics, engendering an inner conflict which threatens their survival.

The first variant of the supercivilisation is characterised by a substantial moderation. From this perspective, the rationalising process is not aimed at exhausting every aspect of existence, but rather at distancing oneself from all that which, in life, does not seem to be already oriented towards a possible objectification. In this way, however, moderatism ends up overlooking some fundamental components of social and political life, i.e. all its emotional and irrational aspects, with the consequence that people cease to find any concrete bond to this impersonal apparatus, which might be even considered as an enemy, an opposing structure which must be destroyed.

The second, more radical version moves in the opposite direction, as - rather than excluding - it essentially aims at subordinating every force which resists its own domination, leading it back to its formalised system of power. «In this radical version,

\footnotetext{
9 About the very broad problematic of «rationalization» understood as the fundamental trait of modernity, see: (Weber, 2012). This work, written by Weber in the first years of twentieth century, has been repeatedly quoted by Patočka in his treatise on supercivilisation.

${ }^{10}$ In the first pages of «Supercivilisation and its Inner conflict», Patočka mentions Weber and some unspecified «Marxist theorists» as those who have succeeded in recognising the «growing rationalization» as fundamental and determining factor of modernity. He could refer here both to Lukács, who analysed Weber's discourse on rationalisation in terms of a process which essentially pertains to capitalism (Lukács, 1971, $88 \mathrm{ff}$.), as well as to the critical theory of Adorno and Horkheimer, who addressed this same issue, but understanding it in a broader sense, as the outcome of the history of civilisation (Adorno, \& Horkheimer, 2002).

${ }^{11}$ In this respect, an important role was played in Czechoslovakia by Karel Kosík who in the Dialectics of the Concrete, published in 1963 and destined to become one of the most representative intellectual sources of the Prague Spring, problematised the concepts of homo oeconomicus and rationalisation, with reference both to the phenomenological tradition, Marxism, and critical theory (Kosík, 1976, 50 ff.).
} 
rational civilization is the answer to all of life's questions; there is not one existential problem for which it does not eventually provide the solution, either positive or negative.» (Patočka, 1996b, 251)

The dichotomy between moderatism and radicalism can be easily contextualised within the world political situation of the 1950s: on the one hand the liberal democracy of western countries, represented by the former, and on the other the pervading bureaucraticism of the socialist states, represented by the latter. ${ }^{12}$ Despite all the differences, both these variants can be interpreted as different ways to establish a rationalisation of the means of power which corresponds to the ultimate end of the supecivilising process. Despite their apparent effectiveness, however, the two variants of the supercivilisation suffer severe setbacks; the outcomes of their processes are indeed - in the case of radicalism - an absent, denied freedom, and - in the case of moderatism - a freedom which is present, and yet emptied of any meaning. Under these circumstances, the aim of creating a perfectly rationalised political space, in which the difference between liberty and necessity could be finally dropped, in light of a higher and more comprehensive impersonal authority, inevitably collapses. Far from achieving a regnum hominis, the supercivilisation ends up establishing nothing but a regimen hominum, in which the fracture between life and world is fixed only at a price of a complete subjection of the former to the latter. Hence, the newborn homo oeconomicus, far from representing in a cogent way the perfect unity craved by the supercivilisation, and the rational, non-violent solution to any conflict, ends up as a slave, in the case of radicalism, since it is deprived of any power of acting freely, or as an outcast, in the case of moderatism, insofar as its values and beliefs are tolerated just as long as they are limited to its private life, without any chance to be actualised in a social and political context.

Despite this critical situation, which frustrates its political project, in light of the historical events that occurred during the second half of the twentieth century, we can see how the supercivilisation seems indeed able to survive, not by addressing its

\footnotetext{
${ }^{12}$ It must be acknowledged, though, that according to Patočka this analogy cannot be perfectly settled, inasmuch as both the opposing actors present historical traits which can be ascribed respectively to moderatism and radicalism.
} 
contradictions, but rather by perpetuating them, and thus acquiring a sclerotic shape.

With regards to the radical system, it also has its own internal dialectics, whose peculiar trait consists in the fact that it does not lead to the dissolution of the system (which is prevented by the numerous devices of a state-organised technique), but rather to a life in contradictions, to the outliving of the contradictions, and hence to an internal slowdown, to the loss of every spontaneity, and then to the stagnation, from which [the system] keeps rousing through abrupt shakes of its whole structure. (Patočka, 1996b, 262)

What Patočka had probably in mind, in conceiving this long-lasting stagnation, was the condition of the countries of Central and Eastern Europe, in which the enthusiastic impulse towards the realisation of socialism was gradually converted into a political morass. In a more general sense, we can see how Patočka's thought is anything but eschatological: the crisis of history does not lead to history's end. Despite the same etymological meaning of the word «crisis» which inevitably suggests a temporary condition destined to lead to recovery or death, ${ }^{13}$ in this particular context «crisis» may actually become endless, notwithstanding all the various forces that aim at accelerating its progress, determining its conclusion.

The same idea of an endless crisis emerges also in the Heretical Essays, written in the early 1970s, after the failure of the Prague Spring — that is after the last chance was lost to re-ignite the embers of rational civilisation. In particular, at the end of the fifth of these essays, Patocka tackled the problem of the technical age: of its decline and its possible end. One of the consequences of the modern technical age, as it emerged from the industrial revolutions and later culminated in the twentieth century, consists for Patočka in the loss of our capability to clearly distinguish between normality and exception, between everydayness and those events that because of their peculiar character are simply irreducible to it. Human institutions - religious, political, economic - have always tried to regulate this dichotomy between what in our lives

\footnotetext{
${ }^{13}$ Notoriously the greek word krisis derives from the verb krinein, which means to separate, decide, and it originally belongs to the medical vocabulary. Both Hippocrates and Galen used it to indicate the turning point in a disease, which might lead either to healing or to death. Recently the idea of an «endless crisis» emerged in medical research (with reference to the medical consequences of the Nuclear fallouts in Chernobyl and Fukushima), as well as in political studies (with reference to the current economic and political crisis). See for example, Caldicott (2014): «The Fukushima disaster is not over and will not end for many millenia. [...] [The radioactive fallout] cannot simply be "cleaned up" and it will continue to contaminate food, humans and animals» (Caldicott, 2014, 3); see also: (Gamble, 2014).
} 
is perceived as normal and those states of exception which threaten to shatter this normality. What distinguishes the technical age from the previous eras is its attempt not just to regulate these two fundamental components of human existence, but to completely eliminate any distinction between them. This leads to a sort of religion of everydayness, which recalls the final stage of the supercivilising project, and whose main characteristic is «boredom» which is not seen here as «something negligible, a "mere mood", a private disposition, but rather the ontological condition of a humanity which has wholly subordinated its life to everydayness and its anonymity.» (Patočka, 1996a, 112) ${ }^{14}$ As in the case of supercivilisation, this perfectly homogeneous structure can be broken only by the most tragic events which characterised twentieth century, whose insurrection reveal its hidden fragility. In this sense, Patočka defines twentiethcentury «war» as «the full fruition of the revolt of the everyday» (Patočka, 1996a, 113). And yet, here too Patocka affirms that even though the technical age seems doomed to a speedy decline, because of its incapacity to prevent this re-emergence of life's shattering and exceptional elements, this conclusion is all but certain: «As to the question whether the industrial civilization is decadent [...], the answer now seems easy. Still, we hesitate about it.» (Patočka, 1996a, 117) It is true, on one side, that this civilisation failed in its most important aim, that is allowing humanity to live an authentic life in this world, and ended up obtaining the opposite outcome, that is an «addiction to things, to their everyday procurement, to bondage to life.» (Patočka, 1996a, 113) Nonetheless,

On the other hand, it is also true that this civilization makes possible more than any previous human constellation: a life without violence and with far-reaching equality of opportunity. Not in the sense that this goal would anywhere be actual, but humans have never before found the means of struggle with external misery, with lack and want, which this civilization offers. (Patočka, 1996a, 118)

Living in a civilisation in crisis, perpetuating its stagnation, seems after all preferable than taking a distance from it, at the risk of running again into that misery, lack, and violence, that the civilisation at least promises to forestall. In other words, an addiction to things appears a better solution than living a completely unsheltered life.

\footnotetext{
${ }^{14}$ In his definition of boredom, Patočka is mainly influenced by Heidegger's insight into this same topic. See in particular: (Heidegger, 1995).
} 


\section{LIFEWORLD AND SYSTEM}

We have seen how Patočka's idea of supercivilisation can be interpreted as a systematic attempt to formalise and rationalise the lifeworld, an attempt to hide its inherent conflicts. Jürgen Habermas, in his analysis of the rationalisation problem, also used similar terms, referring to the idea of «lifeworld» as opposed but also tightly connected to the one of «system».15 Unlike phenomenology, which still conceives lifeworld within the frame of a philosophy of consciousness, ${ }^{16}$ Habermas aims to understand this concept as complementary to the one of «communicative action». According to him, the lifeword represents in fact the framework in which social actors are settled and in which communicative action occurs. The lifeworld can be thus represented by a "culturally transmitted and linguistically organized stock of interpretive patterns», which allow individuals to communicate in a natural and immediate way, by providing them «unproblematic, common, background convictions that are assumed to be guaranteed» (Habermas, 1987, 124). In this respect, Habermas can also add that:

The lifeworld is, so to speak, the transcendental site where speaker and hearer meet, where they can reciprocally raise claims that their utterances fit the world (objective, social, or subjective), and where they can criticize and confirm those validity claims, settle their disagreements, and arrive at agreements. (Habermas, 1987, 126)

For this very reason it is not possible to relate to our own language as we would relate to any physical object, for it is not possible to simply take a step back from the communicative space of the lifeworld in the same way as we can take a distance from someone or something which physically stands in front of us. In this sense, the lifeworld

\footnotetext{
${ }^{15}$ See in particular: (Habermas, 1975; 1987, $113 \mathrm{ff}$.). Whether this dichotomy between lifeworld and system is valid only in the context of Habermas' early philosophical research, or if it is still tenable also in light of his later works on political theory (as I also maintain here) has been object of debate. See on this: (Baxter, 2011; Flynn, 2014; Wirts, 2014).

${ }^{16}$ In order to distinguish his own method from the one of phenomenology, Habermas particularly refers to the social phenomenology developed by Alfred Schütz and Thomas Luckmann (Schütz, \& Luckmann, 1973). According to Habermas' interpretation, the mistake of phenomenology, both in its Husserlian form and in its following development, consists in the fact it sticks with the intuitive method proper of transcendental phenomenology, overlooking the possibility of a communicational-theoretical approach: «This explains why Schütz and Luckmann do not get at the structures of the lifeworld by grasping the structures of linguistically generated intersubjectivity directly, but rather in the mirror of the isolated actor's subjective experience. In the frame of the philosophy of consciousness, the "experiencing subject" remains the court of last appeal for analysis.» (Habermas, 1987, 130)
} 
lasts as a form of horizon; as something that continually changes, along with the change of society and of all its components.

On the other hand, by «system» Habermas means those systems of action — like, for instance, economy or state - which by means of a series of media, like money and power, have generated over the years a series of rules and internal structures which separate them from the subjective position of the social actor, i.e. from their lifeworld, in order to regulate it from the outside. If on one side lifeworld follows the rules of «communicative action» aimed at a mutual understanding, the system undertakes a sort of «strategic action» aimed at objective and determined goals. Society consists thus in the intermingling of lifeworld, when it is conceived from the internal perspective of its actors, and of system, whether it is seen from an external and objective point of view.

In modern societies this balance ends up changing, with the consequence of a detachment of lifeworld from system. On one hand, in light of the increasing complexity of modern societies, the lifeworld undergoes a process of rationalisation, in order to become capable of facing this complexity. An example of this is the shift from a pre-conventional stage of moral consciousness, based on particular expectations of behaviour, to a conventional and post-conventional stage, which determines the birth of formalised and institutionalised forms of law and ethics (Habermas, 1987, 175). On the other hand, the system too becomes more and more complex, by undertaking a process of specialisation and internal differentiation, which ends up creating a sort of separated world, totally disjointed from the norms and the conventions of the lifeworld, and therefore becoming unintelligible for the communicative praxis of everyday life. The result is a harsh separation between the two constitutive elements of society, which resolves itself into an attempt by the system to «colonise» the lifeworld, by transforming it into a mere subsystem: «[T]he more complex social systems become, the more provincial lifeworlds become. In a differentiated social system the lifeworld seems to shrink to a subsystem.» (Habermas, 1987, 173) ${ }^{17}$ As the actions in it are no longer realised by individuals by means of communicative processes, but are instead determined by systematic structures through external media, social actors loses their responsibility. The substitution of the communicative framework with a strategic set of actions, which

${ }^{17}$ About this notion of «colonization» in Habermas, see, for example: (Jütten, 2011). 
corresponds to the juridification and economisation of everyday life, actually deprives human beings of their capability to act responsibly: «If by "responsibility" we mean that one orients one's actions to criticizable validity claims, then a "deworlded" coordination of action that is unhinged from communicatively established consensus does not require that participants be responsible actors.» (Habermas, 1987, 184)

What emerges from this brief reconstruction is first of all how a phenomenological concept, that is «lifeworld» constituted for Habermas a useful category to identify the process which, according to him, is at the origin of modern social pathologies. Secondly, it is also notable how this interpretation acquires for Habermas an even deeper meaning in light of the current economic and political crisis. In an interview with Die Zeit, conducted in 2008 just after the collapse of Lehman Brothers Bank, in which he tries to figure out a positive reaction to the rising crisis, Habermas states that his hope was «that the neoliberal agenda will no longer be accepted at face value but will be opened to challenge. The whole programme of an unscrupulous subordination of the lifeworld to the imperatives of the market must be subjected to scrutiny.» (Habermas, 2012, 104) Reading this passage in light of the uncoupling between lifeworld and system, pinpointed already in The Theory of Communicative Action, enables us to understand the crisis phenomenon as an opportunity to put an end to the colonisation of the lifeworld, by shattering the systemic control to which it is subjected..$^{18}$ This would also entail, returning again to Habermas' terminology, shaping a new kind of political and economic system, opened not only to strategic, but also to communicative action, and thus able to recover a space in itself for personal and political responsibility.

What the current economic and political crisis in Europe has shown, according to Habermas, is the failure of the aforementioned colonisation of the lifeworld or, to put it in other words, the ineffectiveness of that «ordoliberal dream» according to which the EU member states would have automatically conformed to voluntary stability criteria, with no need of joint political decisions (Habermas, 2012, vii). ${ }^{19}$ The emergence of conflicting economic cultures among the various states, as well as of the constantly

\footnotetext{
${ }^{18}$ About the influence of Habermas' political philosophy on his late insight into the present condition of the European institutions and their ongoing crisis, see: (Verovšek, 2012).

${ }^{19}$ On the ordoliberal tradition and its relevance to phenomenology, also in light of the current European political and economic crisis, see: (Miettinen, 2016).
} 
changing environments in which we live, reveals the presence of social and political bases which cannot be easily subdued by any external mechanism, which would be unable to recognise their complex nature. In light of this conflicting situation, we see a deep rift growing between European politics and European people; between existing European institutions, like the European Council or the European Commission, aiming at controlling the member states' conduct from their external position, and the various elements which strive to contrast this «post-democratic exercise of political authority» (Habermas, 2012, viii), by advocating the sacredness of the nation state, or alternatively by endorsing the birth of a European federal state. In order to overcome this impasse, Habermas underlines the need of a constitutional project, aimed at the definition of a new form of European community; not simply an international community of states, but rather a cosmopolitan community of states and world citizens.

The main question is how this passage, which necessarily oversteps the nation state's dimension, could take place without causing the loss of the democratic legitimation which is necessary to the democratic political functioning. In other words, how can we think of Europe as a political conformation which, despite the lack of the internal unity that characterises a nation state, would still represent a community legitimised by its members, i.e. by both its states and its peoples? In this sense, insofar as the crisis which began in 2008 revealed the fragmentation of Europe, an insight into this crisis can perhaps reveal the possibility to create a new interaction between these fragments, beyond any illusion of mere unity. The fact that we cannot simply refer to one «European people» as a homogeneous body, does not prevent, but rather strongly urges us to conceive more complex forms of commonality, on which a future political union could be grounded. ${ }^{20}$ Concretely, this implies imagining new forms of «transnationalization of popular sovereignty [...] in the shape of a democratic alliance of nation states» (Habermas, 2012, 11), without however lowering the level of democratic legitimation. To do this, Habermas aims to remove the «mental block», according to which there cannot be popular sovereignty without state sovereignty, by realising an analysis aimed at the

\footnotetext{
${ }^{20}$ «[T] he enduring political fragmentation in the world and in Europe is at variance with the systemic integration of a multicultural world society and is blocking progress towards civilizing relations of violence within societies and between states through constitutional law.» (Habermas, 2012, 7)
} 
redefinition of the concept of political community, starting from its basic components, namely (1) the democratic association of free and equal legal persons, (2) the organisation of collective decision-making powers, and (3) the medium of integration of civic solidarity among strangers (Habermas, 2012, 13). Once these elements have been unearthed, it also becomes possible to see how, with the passage from nation state to European-level politics, they do not simply vanish, but rather enter a new constellation, still maintaining their full effectiveness. ${ }^{21}$ This reconfiguration enables the origin of a new political community, beyond state sovereignty but without losing the element of legitimation which essentially pertains to the democratic procedure. On the contrary, according to Habermas, in light of the growing complexity of world society, this passage is not only possible, but necessary and in line with the democratic principles.

Habermas' analysis explicitly tends to contrast the «reification» to which popular sovereignty has been subjected, i.e. the tendency to see this phenomenon as exclusively based on unchanging grounds, despite the modifications through which social reality went. In his explanation of the three building blocks of the political system, Habermas refers again to the phenomenological idea of «lifeworld» i.e. of that «shared horizon [...] in which a collective will can take shape through communication.» (Habermas, 2012, 22, n. 31) Regaining this shared horizon would also mean for Habermas reestablishing within the context of this new European constitutional project that element of responsibility which was lost because of the colonisation of the lifeworld. Nonetheless, this same concept of responsibility should also take a more complex form, in order to cope with the change that the European social and political situation underwent. During the European Union's history more and more importance has been in fact given to the «citizens» of Europe, and not only to the European collective actors, such as member states, which however maintain their role within the European regulation. Because of this coexistence, the European Union is characterised by a sort of duality: on one hand the citizens of the Union, and on the other the European states which keep functioning within the European communitarian system. This implies a sort of double responsibility on the part of individuals: «Every citizen participates in the European opinion - and will-formation processes both as an individual European who autonomously says "yes"

\footnotetext{
${ }^{21}$ See on this also: (Habermas, 2001).
} 
and "no" and as a member of a particular nation.» (Habermas, 2012, 37) A new form of community, whose popular sovereignty corresponds to an «originally shared» sovereignty between European citizens and EU member states, must implement this multilevel character, by maintaining this balance between its constituent parts which should both be recognised as equal partners in all the community legislative functions. Only in this way, according to Habermas, would a loss of democratic legitimation be prevented.

One question which remains open in Habermas' argument is that of how the shift from the organisational cores of European member states to a new constitutional community of European citizens - whose outcome would be the birth of a «new constellation» between the three aforementioned components of the political system can actually take place. Can this project be realised within the current European political frame, or is it rather necessary to establish new political institutions which could possibly help to accelerate this transition? In order to try to answer this question, it could be useful to compare the constitutional project envisaged by Habermas and Patočka's insight into the European situation.

\section{RETHINKING THE COMMUNITY}

We have seen so far how both Patočka and Habermas, in addressing the issue of the European civilisation and its crisis, followed two parallel paths. They both started from a reconsideration of the idea of the lifeword, understood in a strongly ethical and political fashion (the space of the human «I can», for Patočka, and the space of the communicative action for Habermas). They both proceeded by identifying the loss of the authentic level of the lifeworld - rationalised by the supercivilising project, according to Patočka, colonised by the system, according to Habermas - as the origin of the modern social pathologies. For Habermas, a possible solution of this situation would consist in fostering a constitutional project oriented toward a post-national constellation of our political space. A fundamental role is here played by the recovery of an element of individual responsibility within the political frame. This same element of responsibility is present also in Patočka who pointed out in the Heretical Essays how the fundamental question that «historical humans» have to face, once they are put in front of the historical crisis that the technical age runs up into, is «whether they are 
still willing to own up to history» (Patočka, 1996a, 118), ${ }^{22}$ that is whether they are ready to behave in an active and responsible way in their present, despite its critical aspects. It is indeed from this position of responsibility, and not from the one of simple consciousness, that history - that is, «the most basic human achievement» (Patočka, 1996a, 153) - should be explained.

Patočka suggested which shape this new insight into history should take in a series of essays he wrote in the same years during which the Heretical Essays were also elaborated (Patočka, 1988). The idea of "post-Europe», which emerges in these writings, can be actually interpreted as a way to handle the never-ending crisis of modernity. Since, as we have seen above, the crisis of the European political project does not determine its conclusion, but rather its stagnation, it follows that we cannot simply escape from crisis. What we can do is rather struggle to reach a new perspective towards Europe, from within its crisis, engendering a sharper insight into it. Post-Europe is not something which stems from Europe's ashes, by means of a liberating rebirth. Concretely, engendering this post-European perspective means for Patočka looking back to Europe's history, to its most meaningful events as well as to its catastrophes. This urgent need of creating a new «historical insight» (geschichtliche Einsicht) (Patočka, 1988, 230) does not consist though in a mere form of knowledge, but rather in a peculiar insight into the moral relations between success and decline, between what makes freedom possible and what prevents it. In this perspective, the historical catastrophes which Europe encountered are understood as events which are capable of shattering reality, breaking its crisis, rather than as ultimate defeats. The new position here described is all but peaceful: starting this historical enquiry entails indeed facing the conflicts which characterise reality, without simply trying to fix them, in order to regain control of the situation. The hope of a new form of political community, beyond the fall of twentieth-century political projects, depends for Patočka on the capacity to fully recognise the importance of this conflicting element, instead of concealing it. The only way to comprehend reality consists neither in dominating it nor in adapting passively to its tendencies. On the contrary, humankind will find a path out of the crisis which permeates its political condition, as soon as it will learn to move «...against the stream and the general attitude of reality»

\footnotetext{
${ }^{22}$ I have partially changed the translation on the basis of the Czech original text (Patočka, 2002, 116).
} 
(Patočka, 1988, 282), that is in a purely conflicting way. ${ }^{23}$

Reading today Patočka's texts on post-Europe gives the chance to reinterpret the «historical insight» that he envisioned as a useful theoretical tool, in view of a general rethinking of the idea and the grounds of today's Europe. In this sense, the two paths followed by Patočka and Habermas, in order to address the European condition and its long-lasting crisis could be actually bridged, even though in a rather negative way. In order to do this, I would like to refer back to the question that has been previously left open, while dealing with Habermas, that is whether his idea of a new constitutional project for Europe should be grounded on the already existing institutions or whether it would rather require the creation of a new political entity. Taking into account Patočka's late output, and especially the texts on the idea of post-Europe, we can think of a possible answer to this question, which seems to reject both these solutions. ${ }^{24}$ The solution which Patočka envisions here is not indeed a political one, or at least it is not political in the common sense of the word. According to his interpretation, envisaging a new «constitution» of Europe requires in fact first and foremost a phenomenological analysis of its fundaments: of its history, conflicts, internal and external relations. In this sense, Patočka's «historical insight» can be interpreted as a new application of the Husserlian Rückfrage (or questioning-back) on Europe. ${ }^{25}$ Only by recovering the foundation meaning of Europe, as well as the authentic sense of lifeworld as the horizon of intersubjectivity, can a new constitutional project be actualised. In this sense, a philosophical and historical insight must forerun any concrete political venture. Every political programme, which aims at fostering the creation of new institutions within the European frame, will have indeed to take into account this backward reflection, which represents for Patočka the most meaningful heritage of phenomenology. ${ }^{26}$

\footnotetext{
${ }^{23}$ Se on this idea of «post-Europe» also: (Tava, 2016).

${ }^{24}$ With this I don't want to contend that Patočka's reflection on Europe, which originated in the peculiar historical context which followed the setback of the Prague Spring in Czechoslovakia, can actually provide a solution to Europe's ongoing political crisis. Yet some concepts that Patočka thematised in his work can contribute to generate new insights into this issue.

25 «[W]e must inquire back into what was originally and always sought in philosophy, what was continually sought by all the philosophers and philosophies that have communicated with one another historically; but this must include a critical consideration of what, in respect to the goals and methods [of philosophy], is ultimate, original, and genuine and which, once seen, apodictically conquers the will.» (Husserl, 1970, 17-18)

${ }^{26}$ See on this point: (Meacham, 2016).
} 
Only doing this, the risk of relapsing again into a new variant of supercivilisation, in which the true concept of reason is substituted by a sclerotised rationalisation, will be eventually avoided.

\section{REFERENCES}

Adorno, T., \& Horkheimer, M. (2002). Dialectics of Enlightenment. Stanford, CA: Stanford University Press.

Árnason, J. P. (2003). Civilizations in Dispute: Historical Questions and Theoretical Traditions. Leiden: BRILL.

Baxter, H. (2011). Habermas: The Discourse Theory of Law and Democracy. Stanford, CA: Stanford University Press.

Blumenberg, H. (1986). Lebenszeit und Weltzeit. Frankfurt a. Main: Suhrkamp.

Caldicott, H. (Ed.). (2014). Crisis without End: The Medical and Ecological Consequences of the Fukushima Nuclear Catastrophe. New York, NY: The New Press.

Flynn, J. (2014). System and Lifeworld in Habermas' Theory of Democracy. Philosophy and Social Criticism, 40 (2), 205-214.

Gamble, A. (2014). Crisis without End? The Unravelling of Western Prosperity. Basingstoke, NY: Pelgrave Macmillan.

Gramsci, A. (1975). Quaderni dal carcere [Prison Notebooks]. Turin: Einaudi. (in Italian). Habermas, J. (1975). Legitimation Crisis. Boston, MA: Beacon Press.

Habermas, J. (1987). The Theory of Communicative Action. Vol. II. Lifeworld and System. Boston, MA: Beacon Press.

Habermas, J. (2001). The Postnational Constellation and the Future of Democracy. In The Postnational Constellation: Political Essays (58-112). Cambridge, MA: MIT Press. Habermas, J. (2012). The Crisis of European Union: a Response. Cambridge, MA: Polity Press. Heidegger, M. (1995). The Fundamental Concepts of Metaphysics: World, Finitude, Solitude. Bloomington, IN: Indiana University Press.

Homolka, J. (2015). The Problem of Meaning in the Rational (Super)Civilisation: Patočka's Interpretation of Modernity after World War II. In L. Učník, I. Chvatík, \& A. Williams (Eds.), Asubjective Phenomenology: Jan Patočka's Project in the Broader Context of His Work (167-186). Nordhausen: Traugott Bautz. 
Husserl, E. (1970). The Crisis of the European Sciences and Transcendental Phenomenology. Evanston, IL: Northwestern University Press.

Jütten, T. (2011). The Colonization Thesis: Habermas on Reification. International Journal of Philosophical Studies, 19 (5), 701-727.

Kosík, K. (1976). Dialectics of the Concrete: A Study on Problems of Man and World. Dordrecht: Reidel.

Lukács, G. (1971). History and Class Consciousness. Cambridge, MA: MIT Press.

Meacham, D. (2016). Supercivilisation and Biologism. In D. Meacham, \& F. Tava (Eds.), Thinking after Europe: Jan Patočka and Politics. London: Rowman and Littlefield International.

Miettinen, T. (2016). Governing with Ideas: On the Phenomenological Roots of the Ordoliberal Tradition. Metodo. International Studies in Phenomenology and Philosophy. (Forthcoming).

Mill, J. S. (2004). On the Definition of Political Economy, and on the Method of Investigation Proper to It. In Essays on Some Unsettled Questions of Political Economy, 222-300. Retrieved from: http://www.gutenberg.org/ebooks/12004

Patočka, J. (1988). Europa und Nach-Europa. Die nacheuropäische Epoche und ihre geistigen Probleme. In K. Nellen, \& J. Němec (Eds.), Ketzerische Essais zur Philosophie der Geschichte und ergänzende Schriften (207-287). Stuttgart: Klett-Cotta.

Patočka, J. (1989a). Edmund Husserl's Philosophy of the Crisis of the Sciences and His Conception of a Phenomenology of the "Life-World". In E. Kohák (Ed.), Jan Patočka: Philosophy and Selected Writings (223-238). Chicago, IL: University of Chicago Press.

Patočka, J. (1989b). The "Natural” World and Phenomenology. In E. Kohák (Ed.), Jan Patočka: Philosophy and Selected Writings (239-272). Chicago, IL: University of Chicago Press.

Patočka, J. (1994). Die Selbstbesinnung Europas. Perspektiven der Philosophie, 20, 241-274. Patočka, J. (1996a). Heretical Essays in the Philosophy of History. Chicago, IL: Open Court. Patočka, J. (1996b). Nadcivilizace a její vnitrní konflikt [The Supercivilization and Its Inner Conflict]. In Péče o duši I. Sebrané spisy: Vol. 1 (243-302) [Care for the Soul I. Selected Works]. Prague: Oikoymenh. (in Czech). 
Patočka, J. (2002). Kacířské eseje o filosofii dějin [Heretical Essays in the Philosophy of History]. In Péče o duši III. Sebrané spisy: Vol. 3 (13-144) [Care for the Soul III. Selected Works]. Prague: Oikoymenh. (in Czech).

Patočka, J. (2008). Přirozený svět jako filosofický problém [The Natural World as a Philosophical Problem]. In Fenomenologické spisy I. Sebrané spisy: Vol. 6 (127-261) [Phenomenological Writings I. Selected Works]. Prague: Oikoymenh. (in Czech). Schütz, A., \& Luckmann T. (1973). The Structures of the Lifeworld. Evanston, IL: Northwestern University Press.

Srubar, J. (2002). Jan Patočka: Phenomenology of Practice. In J. J. Drummond, \& L. Embree (Eds.), Phenomenological Approaches to Moral Philosophy: A Handbook (311-325). Dondrecht: Kluwer.

Tava, F. (2016). The Brave Struggle: Jan Patočka on Europe's Past and Future. Journal of the British Society for Phenomenology, 47 (3).

Verovšek, P. J. (2012). Meeting Principles and Lifeworlds Halfway: Jürgen Habermas on the Future of Europe. Political Studies, 60 (2), 363-380.

Vetter, H. (2003). Lebenswelten: Ludwig Landgrebe - Eugen Fink - Jan Patočka. Frankfurt a. Main: P. Lang.

Weber, M. (2012). The Protestant Ethic and the Spirit of Capitalism. New York, NY: Routledge.

Wirts, A. M. (2014). A Defense of the Lifeworld: The Source of Normativity in a Democracy. Philosophy and Social Criticism, 40 (2), 215-223. 